\title{
Aspidistra crassifila (Asparagaceae), a new species from Guangxi, China
}

\author{
Chun-Rui Lin', Yan Liu", Dong-Xin Nong², Yoshiko Kono ${ }^{3}$ and Ching-l Peng ${ }^{3^{*}}$
}

\begin{abstract}
Background: Aspidistra crassifila Yan Liu \& C.I Peng, a new species of the Asparagaceae from Guangxi Zhuang Autonomous Region, China, is described and illustrated.

Results: The new species is similar to A. subrotata Y. Wan \& C. C. Huang in the perianth lobes triangular-lanceolate and horizontally spreading, but differs by the perianth campanulate, lobes with appendages at base, stamens 6-8 $\mathrm{mm}$ long, filaments enlarged, anthers adnate to perianth tube, connectives extended and upcurved. The chromosome number of the new species was determined to be $2 n=38$, and the karyotype was formulated as $2 n=22 m^{2 S C}+4 s m+12 s t$.

Conclusion: A careful study of the literature, herbarium specimens and living plants, both in the wild and in cultivation in the experimental greenhouse, support the recognition of the new species Aspidistra crassifila, which is described herein. Aspidistra crassifila is currently known only from Shiwandashan Mountains, which lie in southern Guangxi. A line drawing, color plates and a distribution map are given for the new species to aid in identification.
\end{abstract}

Keywords: Aspidistra crassifila; Aspidistra subrotata; Asparagaceae; New species; Chromosome number; Karyotype; Guangxi; China

\section{Background}

The genus Aspidistra Ker-Gawler (Asparagaceae) was established in 1822 and is comprised of ca. 100 species, more than 60 of which occur in China (Lang et al., 1999; Li, 2004; Tillich, 2005, 2008; Hou et al., 2009; Lin et al., 2009, 2010; Liu et al., 2011). In March 2005, during a field trip to Shiwandashan Mountains in southern Guangxi Zhuang Autonomous Region, China, the second author (Yan Liu) collected and brought back a sterile plant of Aspidistra for cultivation, which flowered in Guilin Botanical Garden next spring. We went on another trip to the same locality in Shiwandashan Mountains in January 2007 and were able to collect fruiting materials of this species. Compared with other species of Aspidistra, it was recognized as an undescribed species that differs from congeners in its peculiar adnate stamens with extended and upcurved connectives.

\footnotetext{
*Correspondence: gxibly@163.com; bopeng@sinica.edu.tw

'Guangxi Institute of Botany, Guangxi Zhuangzu Autonomous Region and the Chinese Academy of Sciences, Guilin 541006, P.R. China

${ }^{3}$ Herbarium (HAST), Biodiversity Research Center, Academia Sinica, Nangang,

Taipei 115, Taiwan

Full list of author information is available at the end of the article
}

\section{Methods}

\section{Chromosome preparations}

Somatic chromosomes were examined for plants collected from the type collection (Yan Liu L1380). Root tips were pretreated in $2 \mathrm{mM}$ 8-hydroxyquinoline at $15-18^{\circ} \mathrm{C}$ for about $8 \mathrm{~h}$, then fixed overnight in a 3:1 ethanol-acetic acid solution below $4^{\circ} \mathrm{C}$. The chromosomes were stained with $2 \%$ acetic orcein in $1 \mathrm{~mol} / \mathrm{L}$ hydrochloric acid and observed. Classification of chromosome morphology is based on the position of the centromere, following Levan et al. (1964).

\section{Results and discussion}

Taxonomic treatment

Aspidistra crassifila Yan Liu \& C.-I Peng, sp. nov.-TYPE: CHINA. Guangxi Zhuang Autonomous Region, Fangcheng (City), Shiwandashan Mountains, alt. 980 m, 10 March 2005. Specimens pressed from plants introduced to Guilin Botanical Garden, Guilin City, Yanshan Township on 11 May 2006, Yan Liu L1380 (holotype: IBK; isotype: HAST) 粗丝蜘蛛抱蛋 Figures 1, 2.

Species nova A. subrotatae Y. Wan \& C. C. Huang affinis, sed differt perianthio campanulato (vs. subrotato), lobis basi appendiculatis (vs. non appendiculatis, margine

\section{实}




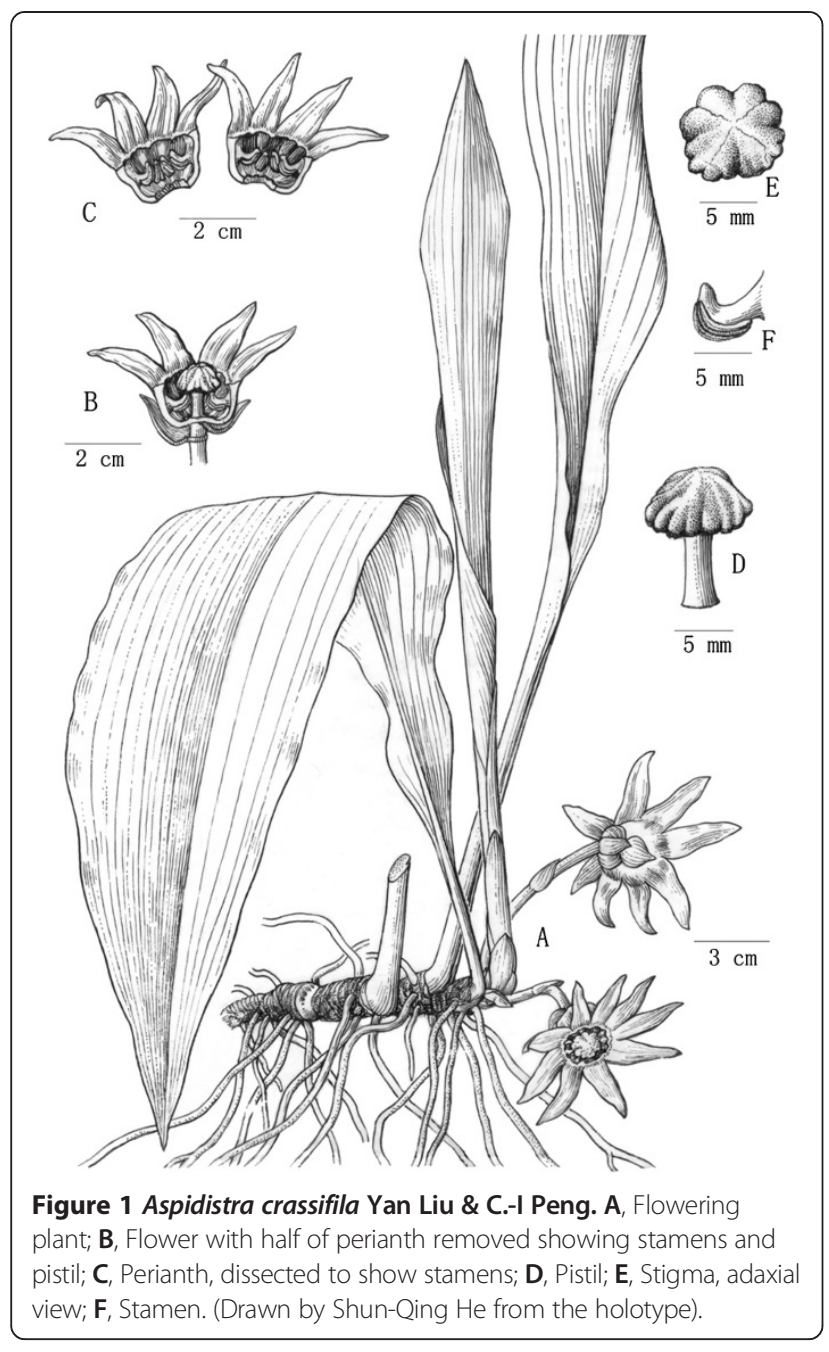

reflexis), filamentis dilatatis (vs. non dilatatis), antheris adnatis (vs. versatilibus), connectivis supra antheras productis (vs. non productis).

\section{Description}

Herbs perennial, evergreen, rhizomatous. Rhizome creeping, subterete, $8-13 \mathrm{~mm}$ thick, covered with scales, nodes dense. Vaginal leaves 4-5, 1-14 cm long, purple-red, enveloping base of petiole, fibrous when withered. Leaves solitary, $2-5 \mathrm{~cm}$ apart; petiole stiff , upright, $10-40 \mathrm{~cm}$ long, 3-5 $\mathrm{mm}$ thick, adaxially sulcate; leaf blade oblongoblanceolate, $30-60 \mathrm{~cm}$ long, 6-12 cm wide, base cuneate, gradually narrowed into petiole, inequilateral, apex acuminate, margin entire. Peduncle purplish red to purplish black, 2.5-6 cm long, with 4-5 bracts, bracts gradually wider from base to top of peduncle; the uppermost bract broadly ovate, purplish red or purplish black, ca. $10 \mathrm{~mm}$ long, ca. $12 \mathrm{~mm}$ wide, apex subobtuse. Flowers solitary; perianth purplish black, fleshy, campanulate, $4-6 \mathrm{~cm}$ in
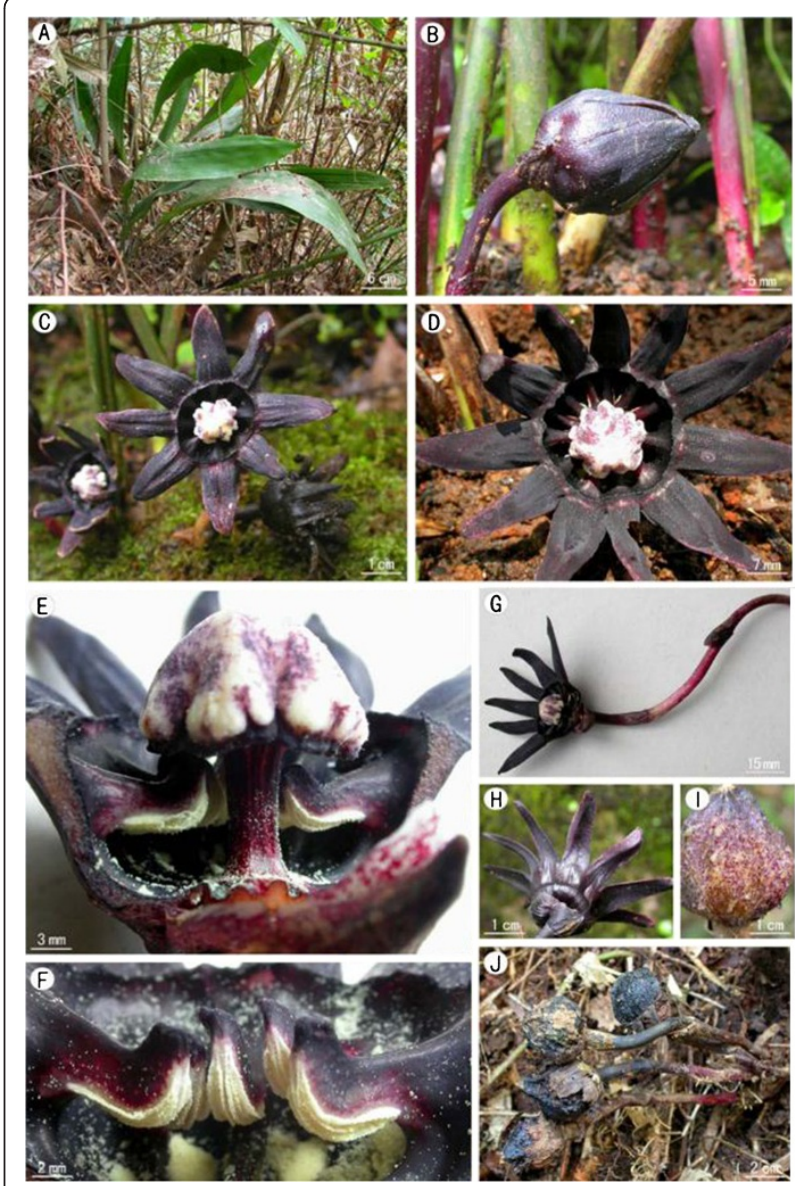

Figure 2 Aspidistra crassifila Yan Liu \& C.-I Peng. A, Habit; B, Bud; C, D, Flowers; E, Flower with half of perianth removed showing stamens and pistil; F, Stamen; G, Flower with peduncle; $\mathbf{H}$, Flower, abaxial view; I, J, Fruit. diam., 8-12 lobed apically; lobes triangular-lanceolate, $15-25 \mathrm{~mm}$ long and 5-10 mm wide at base, apex gradually acuminate, horizontally spreading, with appendages at base, tube $8-12 \mathrm{~mm}$ long, distal opening 15-20 mm diam.; stamens as many as and opposite to lobes, $6-8 \mathrm{~mm}$ long, inserted in the middle of perianth tube, positioned lower than stigma, filaments purplish black, enlarged, 3-4 $\mathrm{mm}$ wide at side view, their upper surfaces visible from above (between adaxial surface of perianth tube and margin of stigma), anthers adnate to perianth, pale yellow, oblong, 5-6 mm long, ca. $2 \mathrm{~mm}$ wide, connectives extended and upcurved; pistil mushroom-shaped, $2 \mathrm{~cm}$ long, style cylindrical, ca. $10 \mathrm{~mm}$ long, ca. $4 \mathrm{~mm}$ across, purplish red, ovary inconspicuous, stigma enlarged, ca. $10 \mathrm{~mm}$ high, $12-15 \mathrm{~mm}$ across, upper surface white with purple spots, smooth, lower surface purplish black, irregularly concaved and undulate at margin. Berry subglobose, ca. $3.5 \mathrm{~cm}$ across, tuberculate. 


\section{Additional specimens examined}

CHINA. Guangxi Zhuang Autonomous Region, Fangcheng (City), Shiwandashan Mountains, alt. 980 m, 10 March 2005, Yan Liu L1156 (IBK); same locality, 17 January 2007, Yan Liu L1425 (IBK).

\section{Chromosome cytology}

The chromosome number of Aspidistra crassifila was determined to be $2 n=38$ (Figure 3 ), showing a trimodal variation in chromosome length at mitotic metaphase. Among the 38 chromosomes, the first two were much longer (ca $10.5-10.6 \mu \mathrm{m}$ ) than the rest; the next 16 gradually varied, ca 3.9-7.5 $\mu \mathrm{m}$; the remaining 20 chromosomes also gradually varied, ca. 1.9-2.8 $\mu \mathrm{m}$ long. Regardless of the chromosome length, 22 (Nos. 1, 2 and 19-38 in Figure 3B), 4 (Nos. 7, 8 and 17, 18 in Figure 3B), 12 (Nos. 3-6 and 9-16 in Figure 3B) had centromere at the median $(\mathrm{m})$, submedian $(\mathrm{sm})$, and subterminal (st) positions, respectively. Secondary constrictions (SC) were

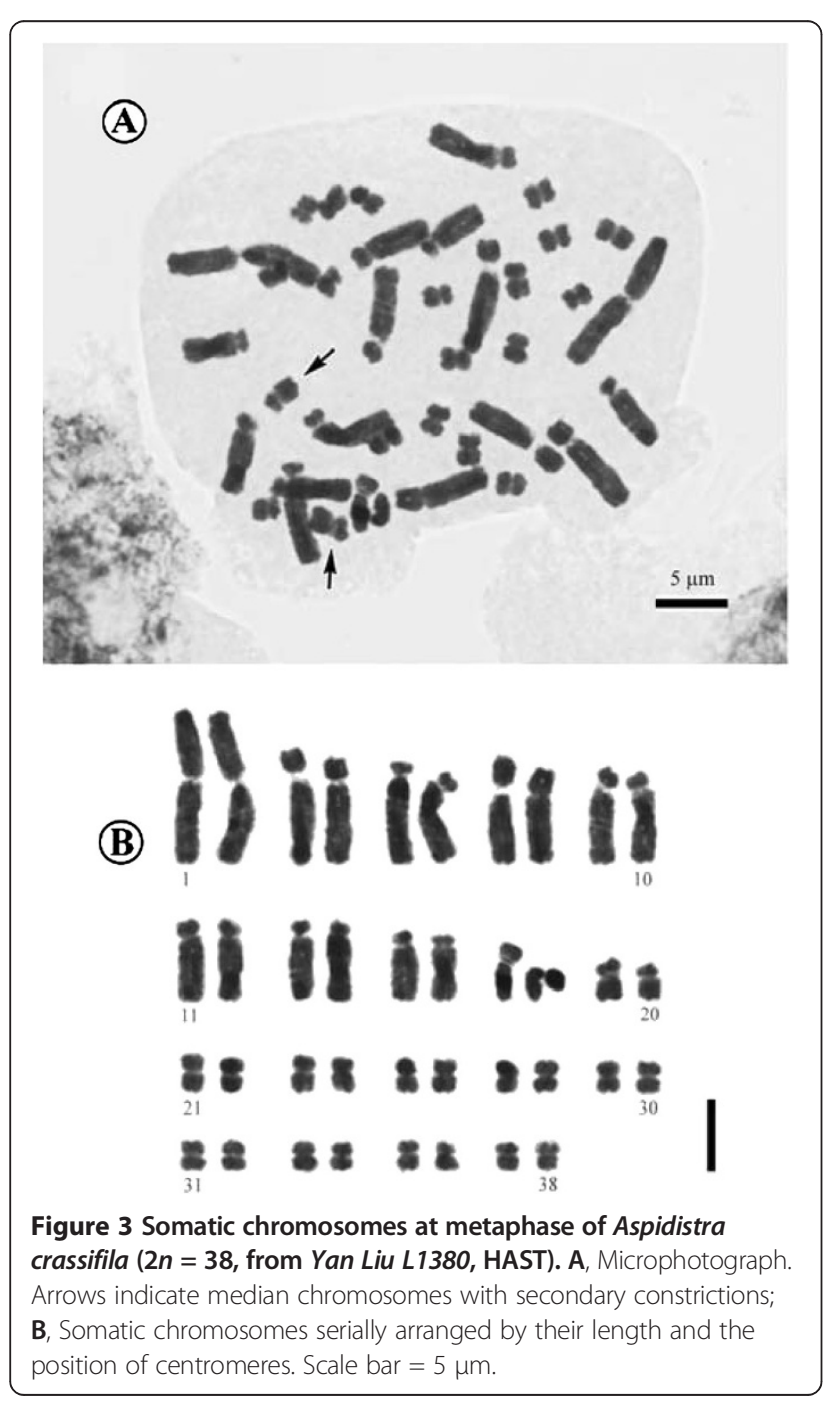

observed at the proximal regions of the short arms in two submedian chromosomes (arrows in Figure 3A; Nos. 19 and 20 in Figure 3B). Thus, the karyotype formula of Aspidistra crassifila is $2 n=38=22 \mathrm{~m}^{2 \mathrm{SC}}+4 \mathrm{sm}+12$ st.

Previously, detailed cytological data were known for 42 species in the genus Aspidistra (Bogner and Arnautov, 2004; Li, 2004; Yamashita and Tamura, 2004; Qiao et al., 2008; Hou et al., 2009, Lin et al., 2010; Liu et al., 2011). Aspidistra crassifila shared a number of cytological features, namely basic chromosome numbers of $x=19$, trimodal chromosome complement, the first pair of longer median chromosomes and 10th median SC-chromosomes, in common with those of the Aspidistra species previously reported (Lin et al., 2010).

\section{Ecology}

On shaded bamboo slopes in seasonal rain forests (monsoon forests).

\section{Distribution}

Currently known only from Shiwandashan Mountains, Fangcheng (City), in southern Guangxi Zhuang Autonomous Region, China (Figure 4).

\section{Phenology}

Flowering from March to May; fruits maturing in May next year.

\section{Etymology}

The specific epithet 'crassifila' is derived from its enlarged filaments.

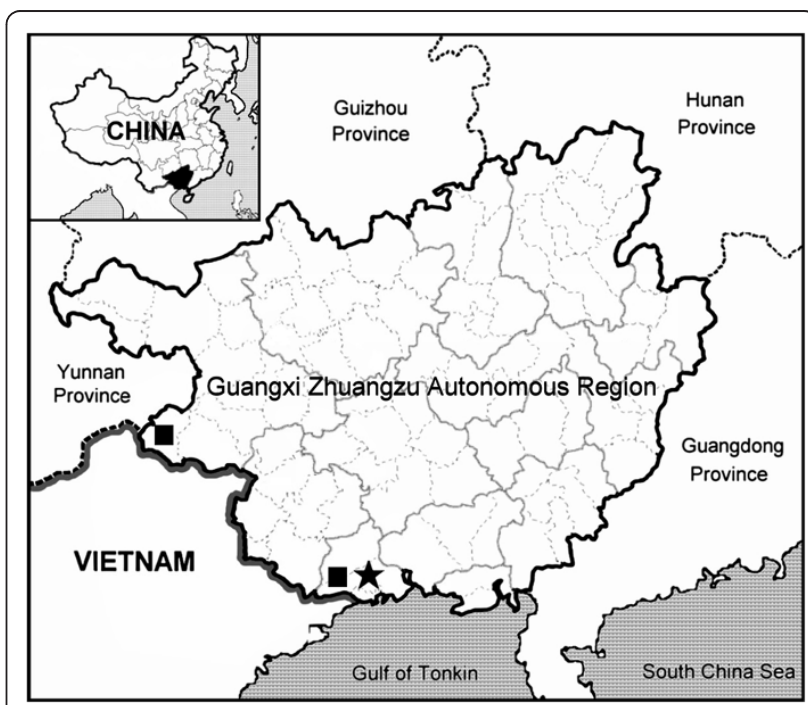

Figure 4 Distribution of Aspidistra crassifila Yan Liu \& C.-I Peng $(\star)$ and A. subrotata Y. Wan \& C. C. Huang ( $₫)$ in Guangxi Zhuangzu Autonomous Region, China. 

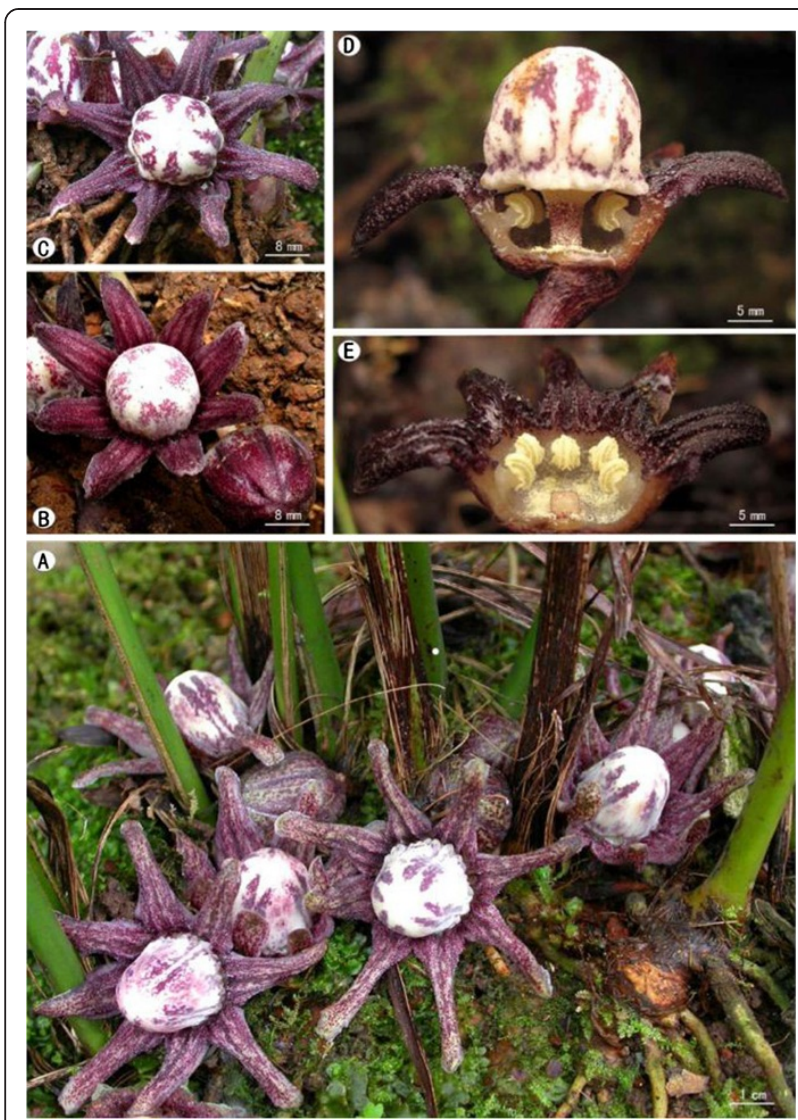

Figure 5 Aspidistra subrotata Y. Wan \& C. C. Huang. A, Habit; B, C, Flowers; D, E, Flower, dissected to show stamens and pistil.

\section{Notes}

Aspidistra crassifila (Figures 1,2) resembles A. subrotata Y. Wan \& C. C. Huang (Figure 5; Wan and Huang, 1987) in the perianth lobes triangular-lanceolate, horizontally spreading, but differs in its perianth campanulate (vs. subrotate), lobes with appendages at base (vs. without appendages, margin reflexed), filaments enlarged (vs. non enlarged), anthers adnate (vs. versatile) to parianth. Connectives extended and upcurved (vs. not extended). Also the purplish black perianth color is rather rare in Aspidistra, known only from A. renatae C. Bräuchler (Bräuchler and Ngoc, 2005), A. nikolai L.V. Averyanov \& H.-J. Tillich (Tillich and Averyanov, 2008), A. atroviolacea H.-J. Tillich (Tillich, 2008), and A. pileata D. Fang \& L. Y. Yu (Fang and $Y u, 2002)$.

\section{Conclusion}

A careful study of the literature, herbarium specimens and living plants, both in the wild and in cultivation in the experimental greenhouse, support the recognition of the new species Aspidistra crassifila, which is described herein. Aspidistra crassifila is currently known only from Shiwandashan Mountains, which lie in southern Guangxi.

\section{Competing interests}

The authors declare that they have no competing interests.

\section{Authors' contribution}

YL discovered the new species and collected field data; CRL, and DXN participated fieldwork and prepared the earlier draft of description; YK performed cytological studies; CIP cultivated the new species to collect morphological and cytological data, and prepared the final manuscript. All authors read and approved the final manuscript.

\section{Acknowledgments}

The authors are grateful to Prof. Fa-Nan Wei (IBK) for Latin diagnosis. We also thank Mr. Shun-Qing He (IBK) for the handsome drawing. This study was supported by the Guangxi Natural Science Foundation (2010GXNSFE013004, 2011GXNSFE18001) to Yan Liu; postdoctoral fellowship from Academia Sinica, Taiwan to Yoshiko Kono; and National Geographic Society Grant \# 8358-07 (Botanical Exploration of Limestone Karsts of Southern Guangxi, China) to Ching-l Peng.

\section{Author details}

${ }^{1}$ Guangxi Institute of Botany, Guangxi Zhuangzu Autonomous Region and the Chinese Academy of Sciences, Guilin 541006, P.R. China. ${ }^{2}$ Guangxi Botanical Garden of Medicinal Plants, Nanning 530023, P.R. China.

${ }^{3}$ Herbarium (HAST), Biodiversity Research Center, Academia Sinica, Nangang, Taipei 115, Taiwan.

Received: 5 March 2013 Accepted: 11 April 2013

Published: 7 October 2013

\section{References}

Bogner J, Arnautov N (2004) Aspidistra locii (Convallariaceae), an unusual new species from Vietnam. Willdenowia 34:203-208

Bräuchler C, Ngoc LH (2005) Aspidistra renatae (Ruscaceae), a new species from central Vietnam. Blumea 50:527-529

Fang D, Yu L-Y (2002) Three new species of Aspidistra Ker-Gawl. (Liliaceae) from Guangxi, China. Acta Phytotax Sin 40:159-163

Hou M-F, Liu Y, Kono Y, Peng C-I (2009) Aspidistra daxinensis (Ruscaceae), a new species from limestone areas in Guangxi. China Bot Stud 50:371-378

Lang K-Y, Li G-Z, Liu Y, Wei Y-G, Wang R-X (1999) Taxonomic and phytogeographic studies on the genus Aspidistra Ker-Gawl. (Liliaceae) in China. Acta Phytotax Sin 37:468-508

Levan A, Fredga K, Sandberg AA (1964) Nomenclature for centromeric position on chromosomes. Hereditas 52:201-220

Li G-Z (2004) The Genus Aspidistra. Guangxi Science \& Technology Publishing House, Nanning

Lin C-R, Liang Y-Y, Liu Y (2009) Aspidistra bamaensis (Ruscaceae), a new species from Guangxi. China Ann Bot Fenn 46:416-418

Lin C-R, Peng C-I, Kono Y, Liu Y (2010) Aspidistra obconica, Asparagaceae [Ruscaceae], a new species from limestone areas in Guangxi. China Bot Stud 51:263-268

Liu Y, Kono Y, Lin C-R, Xu W-B, Peng C-I (2011) Aspidistra erecta (Asparagaceae), a new species from limestone areas in Guangxi. China Bot Stud 52:367-373

Qiao Q, Zhang C-Q, Ma Y-P, Tian W (2008) Karyotype asymmetry of Aspidistra (Convallarieae, Ruscaceae). Acta Bot Yunnan 30:565-569

Tillich HJ (2005) A key for Aspidistra (Ruscaceae), including fifteen new species from Vietnam. Feddes Repert 116:313-338

Tillich HJ (2008) An updated and improved determination key for Aspidistra Ker-Gawl. (Ruscaceae, Monocotyledons). Feddes Repert 119:449-462

Tillich HJ, Averyanov LV (2008) Two new species and one new subspecies of Aspidistra Ker-Gawl. (Ruscaceae) from Vietnam. Feddes Repert 119:37-41

Wan Y, Huang C-C (1987) New species of the genus Aspidistra from Guangxi. Guihaia 7:217-224

Yamashita J, Tamura MN (2004) Phylogenetic analyses and chromosome evolution in Convallarieae (Ruscaceae sensu lato), with some taxonomic treatments. J Plant Res 117:363-370

doi:10.1186/1999-3110-54-43

Cite this article as: Lin et al:: Aspidistra crassifila (Asparagaceae), a new species from Guangxi, China. Botanical Studies 2013 54:43. 